\title{
Antilymphocyte/Thymocyte Globulin for the Treatment of Steroid-Refractory Acute Graft-Versus-Host Disease: 20-Year Experience at a Single Center
}

\author{
Mehmet OZEN ${ }^{1}$, Sinem C. BOZDAG ${ }^{1}$, Guzin CAKMAK ${ }^{2}$, Pervin TOPCUOGLU ${ }^{1}$, Ayse H. EROGLU ${ }^{2}$, \\ Mehmet GUNDUZ ${ }^{1}$, Onder ARSLAN ${ }^{1}$, Taner DEMIRER ${ }^{1}$, Hamdi AKAN ${ }^{1}$, Osman ILHAN', \\ Meral BEKSAC ${ }^{1}$, Gunhan GURMAN ${ }^{1}$, Muhit OZCAN ${ }^{1}$
}

\author{
${ }^{1}$ Ankara University Faculty of Medicine, Department of Hematology and Bone Marrow Transplantation Unit \\ ${ }^{2}$ Ankara University Faculty of Medicine, Department of Internal Medicine, Ankara, TURKEY
}

\begin{abstract}
Although there is currently no consensus regarding the treatment of steroid-refractory acute graft-versus-host disease (GvHD) after hematopoietic stem cell transplantation (HSCT), antithymocyte globulin (ATG) is one of the most widely used immunosuppressive drugs in this setting. We retrospectively summarized our transplant center's experience with 35 steroid-resistant acute GvHD patients who were treated with three different ATG preparations. Severe (grade III-IV) acute GvHD was observed either during the posttransplantation period $(n=32)$ or after donor lymphocyte infusion $(n=3)$. For secondary treatment of acute GvHD, rabbit Jurkat cell linereactive ATG (ATG Fresenius $($ ) $(n=22)$, rabbit thymus cell-reactive ATG (Thymoglobulin $®)(n=9)$ or equine antilymphocyte globulin (ALG) (Lymphoglobulin $\left.{ }^{\circledR}\right)(n=4)$ was administered at a dose of $2-10 \mathrm{mg} / \mathrm{kg} /$ day for five consecutive days. The median time from the diagnosis of acute GvHD to the first day of infusion of ATG or ALG was 15 days (3-70 days). An overall response was observed in 15 patients (42\%), with similar response rates among patients treated with any of the three ATG preparations. The overall survival (OS) of the patients did not increase in any treatment group, though the severity of GvHD and the disease status before HSCT were shown to negatively impact OS. Although responses could be achieved in steroid-refractory acute GvHD using rabbit or horse ATG, survival rates did not increase because of high mortality rates due to infection during treatment.
\end{abstract}

Keywords: Antithymocyte globulin, Antilymphocyte globulin, Acute graft versus host disease

\section{ÖZET}

Steroide Dirençli Akut Graft Versus Host Hastalığının Tedavisinde Antilenfosit / Timosit Globulin: Bir Merkezdeki 20 Yıllık Deneyim

Hematopoetik kök hücre nakli (HKHN) sonrası gelişen steroide dirençli akut graft versus host hastalığı (GVHH) tedavisinde, günümüzde üzerine uzlaşma olmamasına rağmen antitimosit globulin (ATG) bu durumda geniş çaplı olarak kullanılan immünsüpresif ilaçlardan biridir. Üç farklı ATG formu ile tedavi edilen 35 steroide dirençli akut GVHH hastası hakkında nakil merkezimizin tecrübesini geriye dönük olarak özetledik. Ciddi (derece 3-4) akut GVHH nakil sonrası dönemde ( $n=32)$ veya donör lenfosit infüzyonundan sonra $(n=3)$ gözlendi. Akut GVHH'nin ikincil tedavisinde tavşan Jurkat hücre dizisi reaktif ATG (ATG Fresenius $®)$ ( $n=22$ ), tavşan timus hücresi reaktif ATG (Thymoglobulin $囚)(n=9)$ veya at antilenfosit globulin (ALG) (Lymphoglobulin®) ( $n=4)$ ardışık 5 gün boyunca 2-10 mg/kg/gün dozunda uygulandı. Akut GVHH tanısından ATG veya ALG'nin ilk infüzyon gününe kadarki ortanca süre 15 (3-70) gündü. Toplam yanıt 15 (\%42) hastada gözlenirken, üç ATG formunun herhangi biri ile tedavi edilmiş hastalar arasında benzer yanıt oranları vardı. Hastaların toplam sağkalımı (TS) hiçbir tedavi grubunda artmazken, GVHH'nin ciddiyeti ve HKHN öncesi hastalık durumu TS'yi negatif etkiledi. Steroide dirençli akut GVHH'de at veya tavşan ATG kullanımı ile yanıt elde edilmesine rağmen, tedavi sırasındaki infeksiyona bağlı yüksek mortalite oranları nedeniyle sağkalım artmadı.

Anahtar Kelimeler: Antitimosit globülin, Antilenfosit globülin, Akut graft versus host hastalı̆ı̆ 


\section{INTRODUCTION}

Graft-versus-host disease (GvHD) can be defined as an immune-mediated posttransplant complication resulting from the recognition of donor $\mathrm{T}$ cells in an immunosuppressed recipient. In particular, induction of tissue damage and cytokine production by a conditioning regimen promotes the activation of antigen-presenting cells and the proliferation of donor T cells. Alloreactive T cells expand and migrate to target tissues such as the liver, skin and gut. ${ }^{1,2}$ These tissues are responsible of clinical symptoms and outcome of GvHD patients and GvHD is graded by the involvement of these tissues. Grade II-IV acute GvHD is observed in approximately $40 \%$ of HLA-identical sibling transplants and in up to $80 \%$ of unrelated donor transplants. ${ }^{3,4}$ However, the mortality rate among patients with severe (grade III-IV) acute GvHD can range from $70-100 \% .^{5}$

Corticosteroids remain the first-line treatment for acute GvHD. ${ }^{6}$ The use of systemic corticosteroids is recommended as an initial therapy for grade IIIV GvHD6. For the treatment of steroid-refractory acute GvHD, second-line options may include antithymocyte globulin (ATG), extracorporeal photopheresis (ECP), mycophenolate mofetil (MMF), anti-tumor necrosis factor- $\alpha$ (anti-TNF- $\alpha$ ), mammalian target of rapamycin (mTOR) inhibitors and interleukin-2 receptor antibodies. ${ }^{6-8}$ According to treatment guidelines, ATG use in cases of steroidrefractory acute GvHD is at the discretion of the treating physician. ${ }^{6}$ There is also no defined superior therapy in steroid-refractory acute GvHD.

To prevent GvHD, ATG and antilymphocyte globulin (ALG) have been used in conditioning regimens for approximately 30 years to prevent GvHD. ${ }^{9}$ A meta-analysis revealed that the occurrence of reported cases of grade II-IV GvHD was lower in patients who received ATG. ${ }^{10}$

Both rabbit ATG (Thymoglobulin ${ }^{\circledR}$ ) and horse ALG (Lymphoglobulin ${ }^{\circledR}$ ) have been used to treat steroid-refractory acute GvHD in various studies. Additionally, ATG Fresenius ${ }^{\circledR}$ is a purified rabbit anti-human $\mathrm{T}$ lymphocyte immunoglobulin that has been widely used as part of conditioning regimens and is also preferred as a second-line agent for acute GvHD treatment. Unfortunately, the optimum type and dose of ATG are not standardized. ${ }^{11}$
Our single-center retrospective study, which was approved by the institutional ethical committee, aimed to analyze the response rates of steroid-refractory acute GvHD patients treated with different ATG preparations and the impacts of these treatments on overall survival (OS).

\section{PATIENTS and METHODS}

The database of the Ankara University Faculty of Medicine Stem Cell Transplantation Unit was retrospectively analyzed between 1992 and 2012. In this time period allogeneic stem cell transplantation was performed to 828 patients, 377 patients of them were diagnosed with acute GvHD and treated with i.v, oral or local steroid. In total, 35 patients had steroid refractory acute GvHD and received ATG as a second-line treatment for severe (grade III-IV) acute GvHD. These 35 patients were included in the study. In total, 32 of the patients were diagnosed with severe acute GvHD in the 100 days after transplantation, and 3 patients were diagnosed with severe acute GvHD after donor lymphocyte infusion (DLI).

The Glucksberg system is used to grade the severity of acute GvHD. ${ }^{12,13}$ A $1-2 \mathrm{mg} / \mathrm{kg}$ /day i.v. corticosteroid treatment was the initial treatment for all acute GvHD patients in the current study. Patients were considered refractory to the first-line steroid treatment if GvHD progression was noted within 3 days of treatment or if a response could not be achieved within 7 days. ${ }^{2}$ Our institutional policy for the treatment of steroid-refractory acute GvHD was ATG. Therefore, there was no other drug which was approved by local insurance agency. Moreover, ATG must be imported by commercial companies and sometimes was not commercially available in these 7 days. Hence, we gave ATG treatment when it was available. An addition, we performed i.v. ATG treatment in patients having steroid refractory acute GvHD diagnosis after a skin test with ATG to check for allergic or other adverse reactions and infused minimally in 6 hours via a central vein.

For secondary treatment of acute GvHD, rabbit Jurkat cell line-reactive ATG (ATG Fresenius ${ }^{\circledR}$ ), rabbit thymus cell-reactive ATG (Thymoglobulinß) or equine antilymphocyte globulin (ALG) 
(Lymphoglobulin ${ }^{\circledR}$ ) was administered at a dose of $2-10 \mathrm{mg} / \mathrm{kg} / \mathrm{day}$ for five consecutive days. Physician choice and commercial availability were the main factors dictating the ATG dose and type, respectively. Physician also performed and regulated ATG treatment according to patients' clinical conditions. During ATG treatment, we have given prophylactic platelet transfusion in non-bleeding patients having lower platelet count than $30 \times 10^{9} / 1$. Also, red blood cell transfusions have been performed if a patient has hemoglobin levels less than $7 \mathrm{~g} / \mathrm{dl}$ (or less than $10 \mathrm{~g} / \mathrm{dl}$ in patients with cardiac dysfunction).

We defined the response to ATG treatment as overall response which includes partial and complete response. We did not evaluate separately each response subtype. We defined overall response as any significant improvement in patients' symptoms related to GvHD.

\section{Conditioning Regimen}

The most frequently used myeloablative conditioning regimen consisted of cyclophosphamide (CY) $(120 \mathrm{mg} / \mathrm{kg}$ i.v.) in combination with busulfan (BU) $(3.2 \mathrm{mg} / \mathrm{kg}$ i.v. or $4 \mathrm{mg} / \mathrm{kg}$ p.o. $\times 4$ days $)$ or CY $(60 \mathrm{mg} / \mathrm{kg} \times 2$ days $)$ in combination with fractionated total-body irradiation (12 Gy).

Reduced-intensity conditioning regimens were fludarabine (FLU) based and included FLU (30 $\mathrm{mg} / \mathrm{m}^{2}$ i.v. $\times 5$ days) in combination with Melphalan $\left(70 \mathrm{mg} / \mathrm{m}^{2} /\right.$ d i.v. $\times 2$ days $)$ and FLU $\left(30 \mathrm{mg} / \mathrm{m}^{2}\right.$ $\times 6$ days $)$ in combination with $\mathrm{CY}(60 \mathrm{mg} / \mathrm{kg} \times 2$ days).

GVHD prophylaxis consisted of methotrexate (MTX) at $15 \mathrm{mg} / \mathrm{m}^{2}$ on day +1 and $10 \mathrm{mg} / \mathrm{m}^{2}$ on days +3 and +6 (and additionally on day +11 for unrelated donor alloHCT) and daily cyclosporine (CSA) from day -1 (or -3 in for unrelated donor alloHCT) to day +180 .

\section{Donor Selection and Stem Cell Source}

Donors were selected as this order. The first option was well-matched sibling donor. If a recipient did not have any well-matched sibling donor, other potential donors were searched, including non-sibling well-matched other relatives, unrelated well-matched donors, partially matched donors. The HLA match status was defined using refined HLA-matching criteria. Well-matched cases had no identified HLA mismatch, and they had informative data at 6 loci or had allele matching at HLAA, HLA-B, and HLA-DRB1. Partially matched cases had a defined, maximum one locus mismatch and/or missing HLA data.

Stem cells were derived from bone marrow or peripheral blood according to physician or donor choice.

\section{Prophylactic Treatment}

Patients received infectious prophylaxis, including acyclovir, fluconazole, and trimethoprim sulfamethoxazole, along with all conditioning regimens. In addition, antibacterial prophylaxis was administered via ciprofloxacin in myeloablative regimens. During ATG treatment, iv prophylactic ganciclovir was also administrated at a dose of 5 $\mathrm{mg} / \mathrm{kg} /$ day, 5 days.

\section{Statistics}

Numeric variables are represented as the median (range). Although categorical variables were compared by the Chi-square test or Fisher's exact test, the non-parametric Mann-Whitney U test was used for non-categorical variables.

OS was calculated from the date of allogeneic transplantation to the date of exitus or last control day. We taken into account all death reasons when calculating OS. OS duration distributions were estimated using the Kaplan-Meier method and compared using the log-rank test.

All reported $p$ values were two sided, and $p<0.05$ was considered significant. Statistical analysis was performed using SPSS 16.0 software.

\section{RESULTS}

The patient and donor characteristics are provided in Table 1. The median age of the patients was 33 years (17-54). Patient diagnoses included acute leukemia $(\mathrm{n}=17)$, chronic myeloid leukemia $(\mathrm{n}=$ 


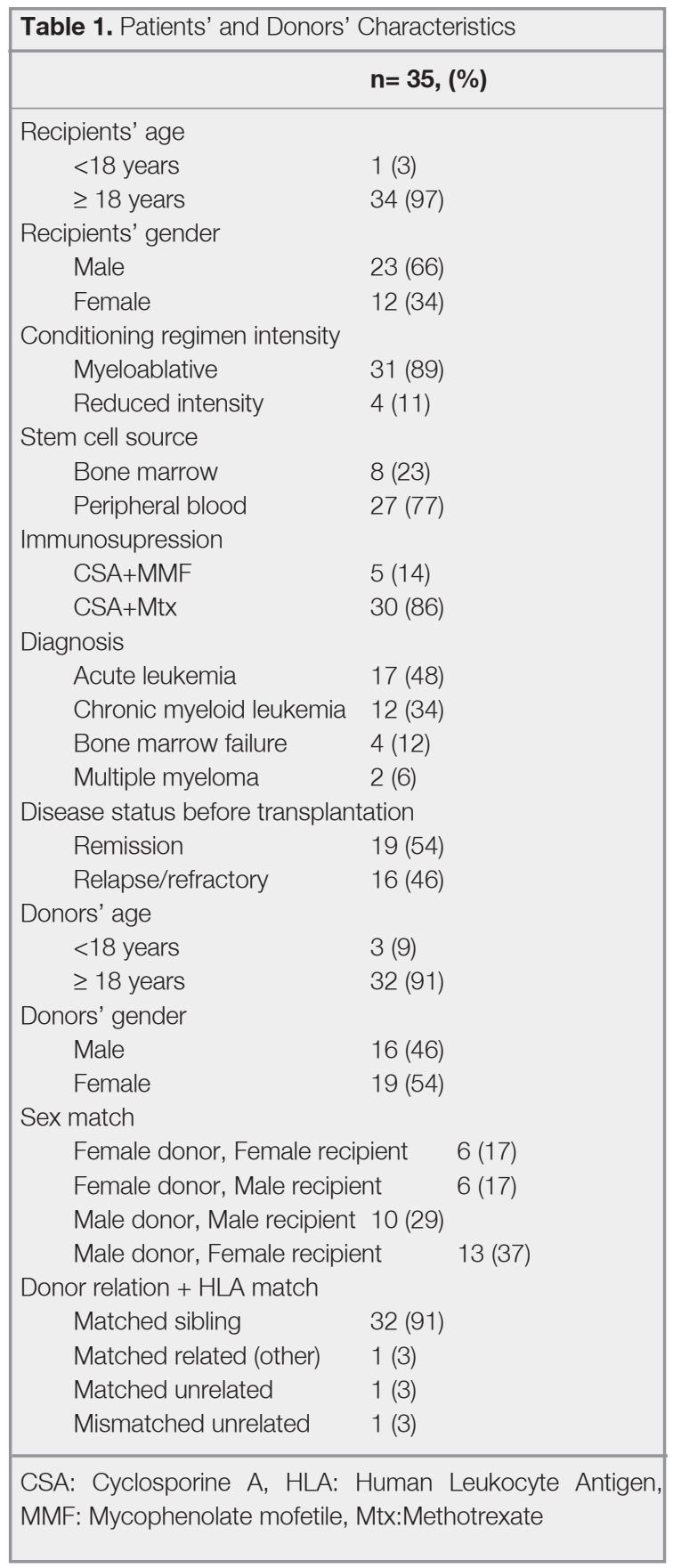

12), bone marrow failure $(n=4)$ and multiple myeloma $(n=2)$. Most patients $(n=31)$ received myeloablative conditioning regimens, and four were treated with reduced-intensity conditioning regimens. All but four patients received cyclosporine A plus methotrexate for GvHD prophylaxis. The major stem cell source was peripheral blood (Table 1).

Gastrointestinal system involvement was observed

\begin{tabular}{|lllll|}
\hline \multicolumn{7}{|l|}{ Table 2. GvHD involvement patterns } \\
\hline $\begin{array}{l}\text { GIS stage } \\
\text { stage }\end{array}$ & $\begin{array}{l}\text { Liver } \\
\text { stage }\end{array}$ & $\begin{array}{l}\text { Skin } \\
\text { stage }\end{array}$ & $\begin{array}{l}\text { Final } \\
\text { grade }\end{array}$ \\
\hline Stage 0 & 3 & 17 & 0 & 0 \\
Stage 1 & 3 & 5 & 13 & 0 \\
Stage 2 & 4 & 4 & 12 & 0 \\
Stage 3 & 9 & 3 & 6 & 14 \\
Stage 4 & 16 & 6 & 4 & 21 \\
GIS: Gastrointestinal System, GvHD: Graft versus Host Dis- \\
ease
\end{tabular}

in 32 patients, and liver GvHD was observed in 18. All patients had skin involvement. All patients had a total Glucksberg score of grade III or IV (Table 2).

For secondary treatment of acute GvHD, ATG Fresenius $(n=22)$, Thymoglobulin $(n=9)$ or Lymphoglobulin $(n=4)$ was administered at a dose of 2-10 $\mathrm{mg} / \mathrm{kg} /$ day for five consecutive days. The median total dose of ATG Fresenius and Thymoglobulin was same and $50 \mathrm{mg} / \mathrm{kg}(10-50)$. The median total dose of Lymphoglobulin was $45 \mathrm{mg} / \mathrm{kg}$ (20-50). The median time between the diagnosis of acute GvHD and the first day of ATG infusion was 15 days (3-70 days).

An overall response was observed in 15 patients (42.8\%); $50 \%$ of responses were observed in the ATG Fresenius group; 22\%, in the thymoglobulin group; and 50\%, in the ALG group. Response rates were similar among the three ATG preparations. The OS of all patients was 5.5 months, and the OS of the patients who received ATG Fresenius, thymoglobulin, or ALG was 3.9 months, 3.4 months and 7.2 months, respectively.

A univariate analysis was conducted to determine which parameters impacted OS (Table 3). OS was not affected by the patients' responses to any of the ATG preparations. GvHD severity and disease status before hematopoietic stem cell transplantation (HSCT) were shown to negatively impact survival. Survival graphs based on the ATG preparation, the acute GvHD grade, the response status and the ATG start time are displayed in Table 4 and Figures 1, 2, 3 and 4, respectively. 


\begin{tabular}{|c|c|c|c|}
\hline & $\begin{array}{l}1 \text { year survival } \\
\% \pm \mathrm{SD} \text {, months }\end{array}$ & $\begin{array}{l}\text { Median } \\
\text { month }\end{array}$ & $\mathbf{p}$ \\
\hline \multicolumn{4}{|l|}{ Diagnosis } \\
\hline Acute leukemia & $11.8 \pm 7.8$ & 3.8 & 0.52 \\
\hline Others & $22.2 \pm 9.8$ & 5.6 & \\
\hline \multicolumn{4}{|c|}{ Disease statement before Tx } \\
\hline Remission & $31.6 \pm 10.7$ & 5.6 & 0.01 \\
\hline Relapse/refractory & $0.0 \pm 0.0$ & 2.9 & \\
\hline \multicolumn{4}{|l|}{ Stem cell source } \\
\hline Peripheral blood & $14.8 \pm 6.8$ & 6.9 & 0.70 \\
\hline Bone marrow & $25.5 \pm 15.3$ & 3.8 & \\
\hline \multicolumn{4}{|l|}{ Recipient gender } \\
\hline Male & $17.4 \pm 7.9$ & 6.4 & 0.93 \\
\hline Female & $16.7 \pm 10.8$ & 3.4 & \\
\hline \multicolumn{4}{|l|}{ Recipient age } \\
\hline$<35$ years & $20.0 \pm 8.9$ & 6.4 & 0.24 \\
\hline 35 years or more & $13.3 \pm 8.8$ & 3.8 & \\
\hline \multicolumn{4}{|c|}{ Time from diagnosis to $\mathrm{Tx}$} \\
\hline 1 year or less & $23.1 \pm 8.3$ & 5.5 & 0.11 \\
\hline$>1$ year & $0.0 \pm 0.0$ & 3.8 & \\
\hline \multicolumn{4}{|l|}{ Donor gender } \\
\hline Male & $12.5 \pm 8.3$ & 3.8 & 0.66 \\
\hline Female & $21.1 \pm 9.4$ & 5.5 & 0.66 \\
\hline \multicolumn{4}{|l|}{ Sex Match } \\
\hline Female to Female & $16.7 \pm 15.2$ & 3.4 & 0.93 \\
\hline Female to Male & $16.7 \pm 15.2$ & 3.4 & \\
\hline Male to Male & $10.0 \pm 9.5$ & 6.4 & \\
\hline Male to Female & $23.1 \pm 11.7$ & 5.6 & 0.93 \\
\hline \multicolumn{4}{|c|}{ Conditioning regimen type } \\
\hline Ablative & $19.4 \pm 7.1$ & 5.5 & 0.35 \\
\hline Reduced intensity & $0.0 \pm 0.0$ & 3.8 & \\
\hline \multicolumn{4}{|l|}{ Immunosupression } \\
\hline CSA+MTX & $20.0 \pm 7.3$ & 5.5 & 0.19 \\
\hline CSA+MMF & $0.0 \pm 0.0$ & 3.8 & \\
\hline \multicolumn{4}{|l|}{ Acute GvHD grade } \\
\hline Grade III & $35.7 \pm 12.8$ & 9.7 & 0.001 \\
\hline Grade IV & $4.8 \pm 4.6$ & 3.4 & \\
\hline \multicolumn{4}{|l|}{ CMV reactivation } \\
\hline No & $12.5 \pm 8.3$ & 3.3 & 0.21 \\
\hline Yes & $21.1 \pm 9.4$ & 6.4 & \\
\hline \multicolumn{4}{|l|}{$\begin{array}{c}\text { Yes } \\
\text { ATG subtype }\end{array}$} \\
\hline Fresenius & $13.6 \pm 7.3$ & 3.9 & 0.79 \\
\hline \multirow{2}{*}{\multicolumn{4}{|c|}{$\begin{array}{c}\text { Others } \\
\text { ATG response }\end{array}$}} \\
\hline & & & \\
\hline No & $15.8 \pm 8.4$ & 3.4 & 0.26 \\
\hline Yes & $18.8 \pm 9.8$ & 6.9 & \\
\hline \multicolumn{4}{|c|}{ ATG starting time from acute GvHD } \\
\hline 3-7 days & $40.0 \pm 21.9$ & 11.5 & 0.15 \\
\hline$>8$ days & $14.8 \pm 6.8$ & 3.8 & \\
\hline
\end{tabular}

The rates of life-threatening bacterial or fungal infection after ATG administration were not significantly different among the three ATG preparations. In ATG-responsive patients $(n=15)$, the causes of death included bacterial or fungal infection in 10 patients, primary disease relapse in 2 patients, chronic GvHD in 2 patients and gastrointestinal bleeding in 1 patient. In the nonresponsive group $(n=20), 19$ patients were not able to receive any other treatment for acute GvHD and died from bacterial or fungal infections with complications of acute GvHD. Only one patient having acute 
International Journal of Hematology and Oncology

Table 4. Comparison of ATG subtypes

\begin{tabular}{|c|c|c|c|}
\hline & $\begin{array}{l}\text { ATG Fresenius } \\
\text { n (\%) }\end{array}$ & $\begin{array}{l}\text { Others } \\
\text { n (\%) }\end{array}$ & p \\
\hline \multicolumn{4}{|l|}{ Total GvHD grade } \\
\hline Grade 3 & $10(46)$ & $4(31)$ & 0.49 \\
\hline Grade 4 & $12(54)$ & $9(69)$ & \\
\hline \multicolumn{4}{|c|}{ Disease status before $T x$} \\
\hline Remission & $12(54)$ & $7(54)$ & 1.0 \\
\hline Relapse/refractory & $10(46)$ & $6(46)$ & 1.0 \\
\hline \multicolumn{4}{|l|}{ ATG overall response } \\
\hline No & $11(50)$ & $9(69)$ & 0.31 \\
\hline Yes & $11(50)$ & $4(31)$ & \\
\hline \multicolumn{4}{|c|}{ Infections after response } \\
\hline Yes & $9(82)$ & $2(50)$ & 0.5 \\
\hline No & $2(18)$ & $2(50)$ & \\
\hline
\end{tabular}

ATG: Antithymocyte Globulin, GvHD: Graft versus Host Disease, Tx: Transplantation

GvHD could get another therapy and the patient responded to intrahepatic arterial steroid treatment and is still alive.

\section{DISCUSSION}

Despite advances in GvHD prophylaxis, acute GvHD remains one of the major causes of morbidity and mortality in allogeneic HSCT. Although steroids have been accepted as a standard first-line treatment for acute GvHD, no second-line treat-

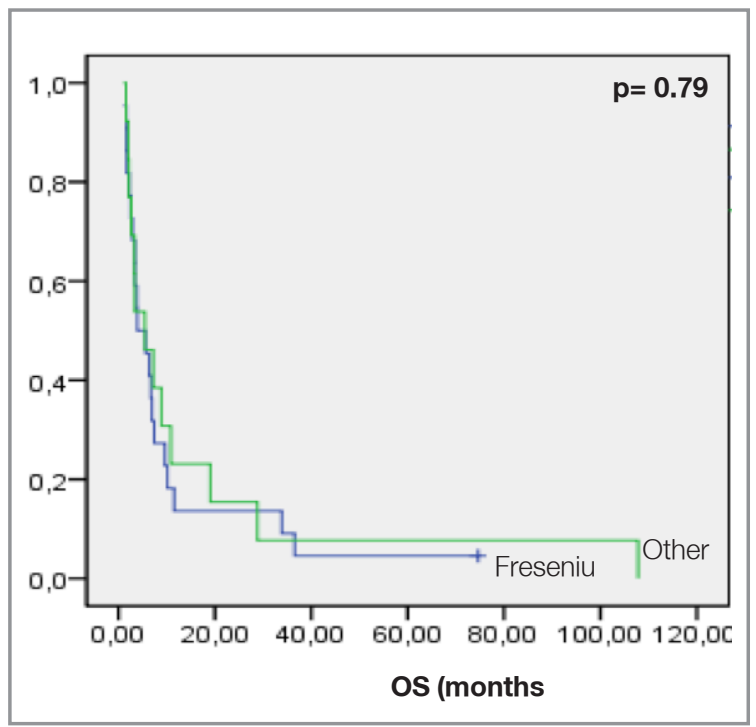

Figure 1. Comparison of patients' overall survival treated with ATG fresenius and others

OS= Overall survival ment option has been found to be more effective than another in treating steroid-refractory acute GvHD patients. Both rabbit and horse ATG have been studied for the treatment of these patients. The number of patients in our study might appear to be small; however, to our knowledge, our study is one of the most comprehensive studies in the literature.

In one of the largest GvHD studies, horse ATG was used in 79 steroid-refractory acute GvHD patients. The overall response rate was $54 \%$, but complete

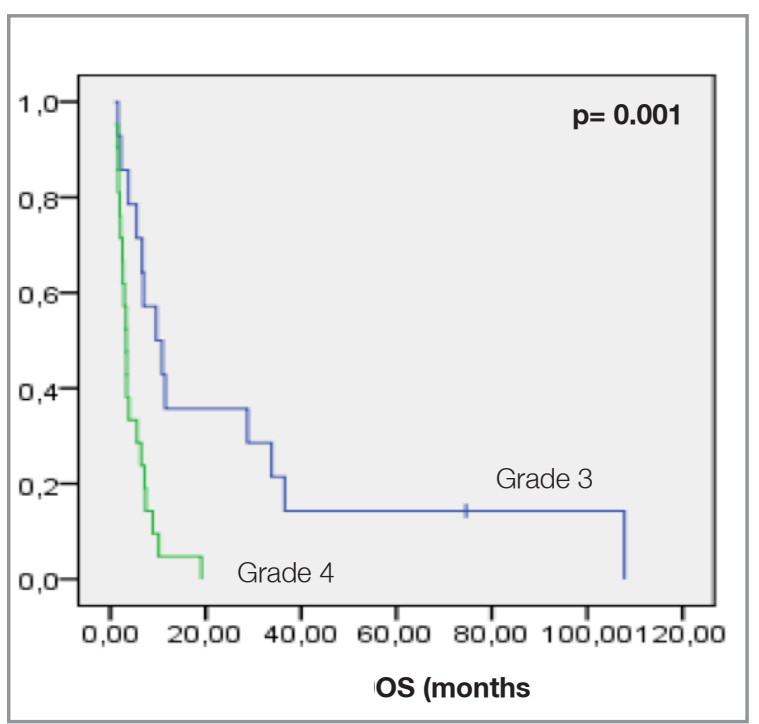

Figure 2. Comparison of patients' overall survival having grade 3 and 4 acute GvHD

OS= Overall survival 


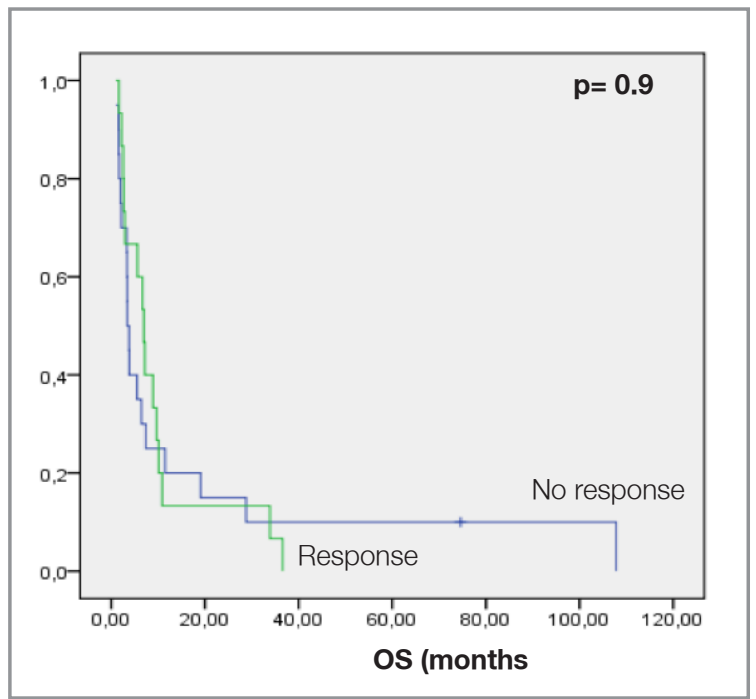

Figure 3. Comparison of Patients' Overall Survival According to ATG Response Statue: Response and Non-Response

remission on the 28th day of treatment was observed in only $20 \%$ of the patients. ${ }^{8}$ In another study with horse ATG, overall improvement was observed in $30 \%$ of the patients, yet $90 \%$ of them died within a median of 40 days of ATG treatment due to complications such as infection or relapse. ${ }^{14}$ McCaul et al. treated patients with rabbit ATG (thymoglobulin) and achieved 59\% overall and 31\% complete response rates. ${ }^{15}$ Van Lint et al. compared rabbit ATG and higher methylprednisolone doses in patients who had not responded after 5 days of the standard $2 \mathrm{mg} / \mathrm{kg} /$ day methylprednisolone dose and found similar response rates. ${ }^{16}$ These studies include more unrelated transplantation than ours. However, the OS of our patients was lower than reported studies. This result was most likely observed because our study included higher-grade (Grade III-IV) GvHD patients. Therefore there is a delay between the diagnosis of acute GvHD and starting ATG due to commercial availability in our country. This aspect may play a role in low OS rates. Figure 4 may suggest that time may play a role in this issue but it might not reach significant level due to less number of patients.

ATG Fresenius, a polyclonal antiserum against the Jurkat cell line, has been widely used in conditioning regimens, but large-series studies of its impact on steroid-refractory acute GvHD have been lacking. The results of treatment with ATG Fresenius have been described in only small series of GvHD

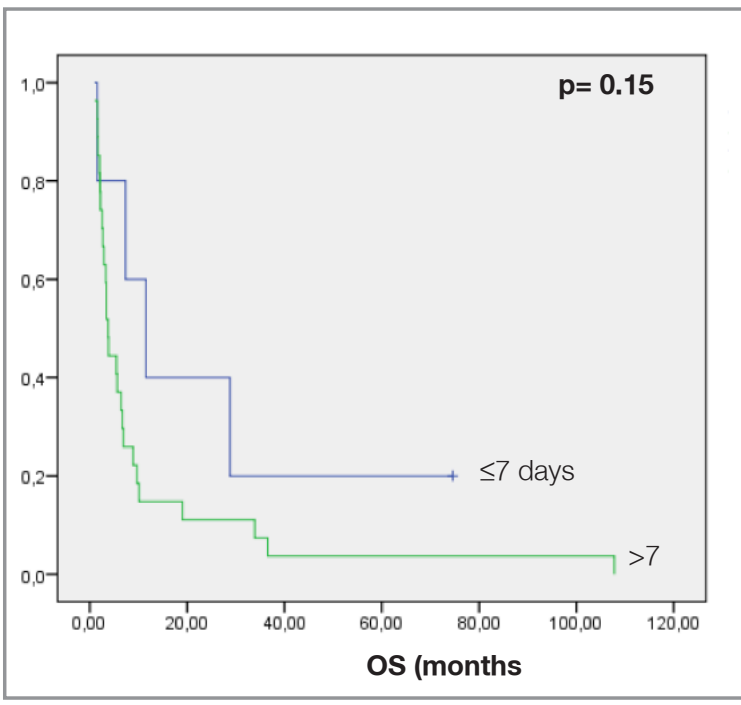

Figure 4. Comparison of Patients' Overall Survival According to ATG Starting Day: Within 7 days and More

patients. ${ }^{7}$ Remberger et al. used five different ATG preparations, including ATG Fresenius, with poor outcomes. ${ }^{7}$ Our study used three different ATG preparations: horse ATG, rabbit ATG and ATG Fresenius. We reported a $42 \%$ overall response rate in all patients, including 50\% with ATG Fresenius treatment, $22 \%$ with thymoglobulin and $50 \%$ with ALG. The response rates in our study were not found to be significantly different among the groups.

The impact of ATG on steroid-refractory acute GvHD can differ according to the involved organ. The skin has been shown to be the most responsive organ in prior studies. ${ }^{13,17}$ In contrast to the skin, liver and gastrointestinal involvement in acute GvHD responds weakly to ATG treatment. In our study, all patients had skin involvement. We did not evaluate organ responses, but the overall response rate was $42 \%$ across all patient groups.

Unfortunately, the response to ATG treatment was not in agreement with the long-term survival rates and the 1-year survival range of $12-34 \%$ previously reported in different studies of acute GvHD patients. ${ }^{7,16,17}$ Macmillan et al. found that the factors associated with better survival included an earlier onset of acute GvHD, use of non-T-cell-depleted grafts and a shorter time from initial treatment to ATG administration. ${ }^{8}$ In our study, OS was 5.5 months for all patients, 3.9 months for those treated 
with ATG Fresenius, 3.4 months for thymoglobulin and 7.2 months for ALG, and OS did not vary with the ATG administration time.

The severity of GvHD and the disease status before HSCT were the only factors associated with survival in our study. OS was not affected by the patients' responses to any ATG preparation. Despite the response rates, complications related to ATG treatment could result in poor patient outcomes. Increased infection rates are one of the major complications of ATG treatment, and most deaths in previous studies were infection related. ${ }^{16}$ In our study, 10 of 15 responsive patients and 19 of 20 nonresponsive patients died due to infections, and we did not observe a difference in infection rates among the three different ATG preparations. We did not evaluate the ATG response type, including partial and complete responses; we only evaluated the overall response. However, we can state that although patients can achieve a response with ATG treatment, it may not affect OS in steroidrefractory acute GvHD patients due its infectious complications.

The treatment doses of ATG preparations differ according to the source. Horse ATG has been mostly administered at $10-15 \mathrm{mg} / \mathrm{kg} /$ day for five consecutive days. ${ }^{8}{ }^{813}$ Arai et al. used an every-other-day dose schedule for 7 consecutive days to decrease the complication rates in their study. ${ }^{17}$ Rabbit ATG doses differed in previous studies, including 6.25 $\mathrm{mg} / \mathrm{kg} /$ day for 10 days and $2.5 \mathrm{mg} / \mathrm{kg} /$ days for $4-6$ consecutive days. ${ }^{15,16}$ One limitation in our study was that patients received ATG Fresenius and thymoglobulin at doses similar to those used for horse ATG due to physician choice or adverse effects. Although ATG Fresenius has been used at 10-20 $\mathrm{mg} / \mathrm{kg} / \mathrm{day}$ for 3 days in conditioning regimens, there is no standard approach for dosing in steroidrefractory acute GvHD cases.

In conclusion, we retrospectively reviewed the results of patients with steroid-refractory GvHD using three different ATG preparations and could not identify a significant advantage of using one preparation over another in terms of response, survival or side effects and we may state that ATG for steroid refractory acute GvHD is not an effective treatment and other therapies may be used instead.

\section{REFERENCES}

1. Socié G, Blazar BR. Acute graft-versus-host disease: from the bench to the bedside. Blood 114: 4327-3436, 2009.

2. Garnett C, Apperley JF, Pavlu J. Treatment and management of graft-versus-host disease: improving response and survival. Ther Adv Hematol 4: 366-378, 2013.

3. Weisdorf D, Hakke R, Blazar B, et al. Risk factors for acute graft-versus-host disease in histocompatible donor bone marrow transplantation. Transplantation 51: $1197-$ 203, 1991.

4. Beatty PG, Hansen JA, Longton GM, et al. Marrow transplantation from HLA-matched unrelated donors for treatment of hematologic malignancies. Transplantation 51: 443-447, 1991.

5. Ringdén O, Nilsson B. Death by graft-versus-host disease associated with HLA mismatch, high recipient age, low marrow cell dose, and splenectomy. Transplantation 40: 39-44, 1985.

6. Dignan FL, Clark A, Amrolia P, et al. Diagnosis and management of acute graft-versus-host disease. Br J Haematol 158: 30-45, 2012.

7. Remberger M, Aschan J, Barkholt L, Tollemar J, Ringdén O. Treatment of severe acute graft-versus-host disease with anti-thymocyte globulin. Clin Transplant 15: 147153, 2001.

8. MacMillan ML, Weisdorf DJ, Davies SM, et al. Early antithymocyte globulin therapy improves survival in patients with steroid-resistant acute graft-versus-host disease. Biol Blood Marrow Transplant 8: 40-46, 2002.

9. Bacigalupo A. Antilymphocyte/thymocyte globulin for graft versus host disease prophylaxis: efficacy and side effects. Bone Marrow Transplant 35: 225-231, 2005.

10. Theurich S, Fischmann H, Chakupurakal G, et al. Antithymocyte globulins for post-transplant graft-versus-host disease prophylaxis-A systematic review and meta-analysis. Crit Rev Oncol Hematol 88: 178-186, 2013.

11. Hsu B, May R, Carrum G, Krance R, Przepiorka D. Use of antithymocyte globulin for treatment of steroid-refractory acute graft-versus-host disease: an international practice survey. Bone Marrow Transplant 28: 945-950, 2001.

12. Glucksberg $H$, Storb $R$, Fefer A, et al. Clinical manifestations of graft-versus-host disease in human recipients of marrow from HL-A-matched sibling donors. Transplantation 18: 295-304, 1974.

13. Przepiorka D, Weisdorf D, Martin P, Klingemann HG, Beatty P, Hows J, Thomas ED. 1994 Consensus Conference on Acute GVHD Grading. Bone Marrow Transplant 15: 825-828, 1995. 
14. Khoury H, Kashyap A, Adkins DR, et al. Treatment of steroid-resistant acute graft-versus-host disease with anti-thymocyte globulin. Bone Marrow Transplant 27: 1059-1064, 2001.

15. McCaul KG, Nevill TJ, Barnett MJ, et al. Treatment of steroid-resistant acute graft-versus-host disease with rabbit antithymocyte globulin. J Hematother Stem Cell Res 9: 367-374, 2000.

16. Van Lint MT, Milone G, Leotta S, et al. Treatment of acute graft-versus-host disease with prednisolone: significant survival advantage for day +5 responders and no advantage for nonresponders receiving anti-thymocyteglobulin. Blood 107: 4177-4181, 2006.

17. Arai S, Margolis J, Zahurak M, Anders V, Vogelsang GB. Poor outcome in steroid-refractory graft-versus-host disease with antithymocyte globulin treatment. Biol Blood Marrow Transplant 8: 155-160, 2002.

\section{Correspondence}

Dr. Muhit ÖZCAN

Ankara Üniversitesi Tıp Fakültesi

Hematoloji Bölümü

Kemik lliği Transplantasyonu Birimi

Cebeci Hastanesi

Dikimevi, ANKARA/TURKEY

Tel: (90-312) 4663550

Fax: (90-312) 4663551

e-mail: ozcan@hemoterapi.com

muhit.ozcan@medicine.ankara.edu.tr

www.muhitozcan.com 